\title{
Horizontal Distributions and Their Ecotoxicological Implications Relating to PCBs, DDTs, HCHs, and HCB in Sediments in the West Nakdong River
}

\author{
Sung-Ug We, Cho-Hee Yoon and Byung-Yun Min*

\section{Department of Environmental Engineering, Kyungnam University, Changwon 631-701, Korea}

Received November 2, 2011 /Revised February 3, 2012 / Accepted February 13, 2012

\begin{abstract}
Horizontal distributions and their ecotoxicological implications relating to organochlorine compounds (OCs) were determined in surface sediments sampled from the West Nakdong River. The concentrations of polychlorinated biphenyls (PCBs), dichlorodiphenyltrichloroethanes (DDTs), hexachlorocyclohexanes $(\mathrm{HCHs})$, and hexachlorobenzene $(\mathrm{HCB})$ in surface sediments were in the range of $0.57-3.68,0.41-8.35,0.63-1.65$, and n.d. $-0.56 \mathrm{ng} / \mathrm{g}$, respectively. DDTs represent the major OC in the West Nakdong River. Concentrations of PCBs and DDTs correlate with the total organic carbon (PCBs: $r=0.874, p<0.001$, and DDTs: $r=0.762, p<0.05$, respectively), indicating that organic content in the sediments is one of the major factors for influencing horizontal distribution of the organochlorine compounds in this river. Examining the potential poisonous character of the surface sediments to benthic organisms according to the sediment quality guideline (SQG), set out by the Canadian Council of Ministers of the Environment (CCME) and the National Oceanic and Atmospheric Administration (NOAA), we found that the concentrations of total PCBs, p, p'-DDD, and $\gamma-\mathrm{HCH}$ were lower than the effects range-low (ER-L) and the probable effects level (PEL). As a result, it is considered that the effect of organochlorines in the region considered on benthic organisms is very low from the perspective of environmental toxicology. However, in terms of the Canadian SQC, $p, p^{\prime}-\mathrm{DDE}, p, p^{\prime}-\mathrm{DDT}$, and total DDTs, respectively, exceeded the interim sediment quality guidelines (ISQG) and the threshold effect level (TEL) in 30\%, 17\%, and 19\%, respectively, of the sediment samples analyzed.
\end{abstract}

Key words : OCs, Sediments, west Nakdong River, horizontal distribution, environmental toxicology

\section{서 론}

대부분 의도적으로 제조된 많은 종류의 잔류성유기오염물 질(Persistent Organic Pollutants, POPs)은 환경 중에 배출되 어 악영향을 미치고 있으며, 특히, PCBs (Polychlorinated biphenyls), OCPs (Organochlorine pesticides) 등과 같은 유기 염소계화합물은 물리 - 화학적으로 안정되어 환경 중에 유입 되면 높은 잔류성과 생물독성이 강한 환경오염물질이다[28]. 또한, 수역에 배출된 지용성인 유기염소계화합물은 유기물질 로 흡착, 분배되어 그 입자성물질은 저층으로 침강-퇴적되며, 저서생물에 의해 이용된다[26]. 이들 축적된 유기염소계화합 물은 먹이사슬의 하위단계에서 상위단계로 전위되어 생태계 내 먹이사슬에 따라 이동하면서 생물 - 농축되고 최종적으로 인체 내 갑상선 호르몬 대사 방해와 같은 내분비계 교란을 일으킨다[2,31]. 이러한 생체독성으로 인하여 국내에서 PCBs 는 1979년에 직접유통이 금지되었으며, 1996년까지 약 4,292 톤의 PCBs가 사용되었다[3]. 유기염소계농약은 1970년대 이 후 수입 및 사용이 금지되었으나[19] 이들 유기염소계화합물 은 인체시료에서 현재까지 검출되고 있다[29].

*Corresponding author

Tel : +82-55-249-2547, Fax : +82-505-999-2166

E-mail : iesi1218@kyungnam.ac.kr
서낙동강 유역은 한국 내에서 최장 수계인 낙동강하류 서남 부에 위치한 수역으로서 일부 산업단지를 제외하고 대부분의 유역이 농업지역으로 생물상이 풍부하다. 그러나, 조류의 흐 름이 여러 수문에 가로막혀 낙동강 본류와 차단됨으로써 하구 호와 같은 상태를 이루고 있으며, 서낙동강 주변지역에서 배 출된 육상기인 유기오염물질이 다양한 경로를 통하여 유입되 면서 주변 생태계 악영향이 예상되나 이들 화학물질의 독성영 향에 관한 오염도 평가는 미미한 실정이다. 수계의 퇴적물은 유기, 무기물의 순환과정에 대한 최종 침전장소이자 원천으로 역할을 담당하고 있어 퇴적물이 오염되면 생태계에 많은 유해 한 영향[21]이 나타나는 것으로 알려져 있으며, 특히, 하구와 연근해에 침강된 오염 퇴적물 중에 유기염소계화합물은 수생 생태계에서 가장 중요한 오염원으로 작용하는 물질로 알려져 있다[11]. 따라서 저서생물을 포함하여 수생 생태계를 보호하 기 위해서는 퇴적물의 오염도를 평가하고 관리할 필요성이 있다.

본 연구에서는 유엔환경계획(United Nations Environment Programme, UNEP)에서 배출감소 및 규제를 위한 우선적 오 염물질로 규정하고 있는 잔류성유기오염물질 중 서낙동강 수 계에 영향을 미칠 수 있는 $\mathrm{PCBs}, \mathrm{DDTs}, \mathrm{HCHs}$ 및 $\mathrm{HCB}$ 등의 수평적 분포에 따른 오염도를 파악하고 퇴적물 오염기준을 이용하여 독성학적 관점에서 저서생물에 미치는 잠재적인 생 
태독성 영향력을 평가하였다.

\section{재료 및 방법}

\section{시료채취}

시료 채취는 서낙동강 수계에서 2004년 3월부터 12월까지 그랩 채니기(Van-veen grab sampler)를 이용하여 3개월 간격 으로 10 개 정점에서 약 $2 \mathrm{~cm}$ 이내의 표층(총 30 개 표층퇴적물) 을 채취하였으며, 시료채취지점은 Fig. 1에 나타내었다. 채취 된 표층퇴적물은 용매로 세척된 폴리에틸렌 비닐 백에 넣어 밀봉한 후 드라이아이스가 들어있는 아이스박스에 담아 실험 실로 이송한 다음 분석 전까지 동결상태로 $-20^{\circ} \mathrm{C}$ 에서 보관하 였다.

\section{분석방법}

유기염소계화합물인 PCBs 및 DDTs, $\mathrm{HCHs}, \mathrm{HCB}$ 의 주요 분석과정은 다음과 같다. 속슬렛 추출용 원통여지에 건조된 표층퇴적물 $10 \mathrm{~g}$ 을 칭량하여 속슬렛 추출기에 넣고, 내부표준 물질 dibromooctafluorobiphenyl, PCB 103 그리고 PCB 198을 각각 $10 \mathrm{ng}$ 첨가한 다음 염화메티렌(ultra residue analysis, J.T. Baker, USA)을 추출용매로 16시간 이상(추출 회차수 24회 이상) 추출하였다. 추출액은 회전증발농축기를 이용하여 약

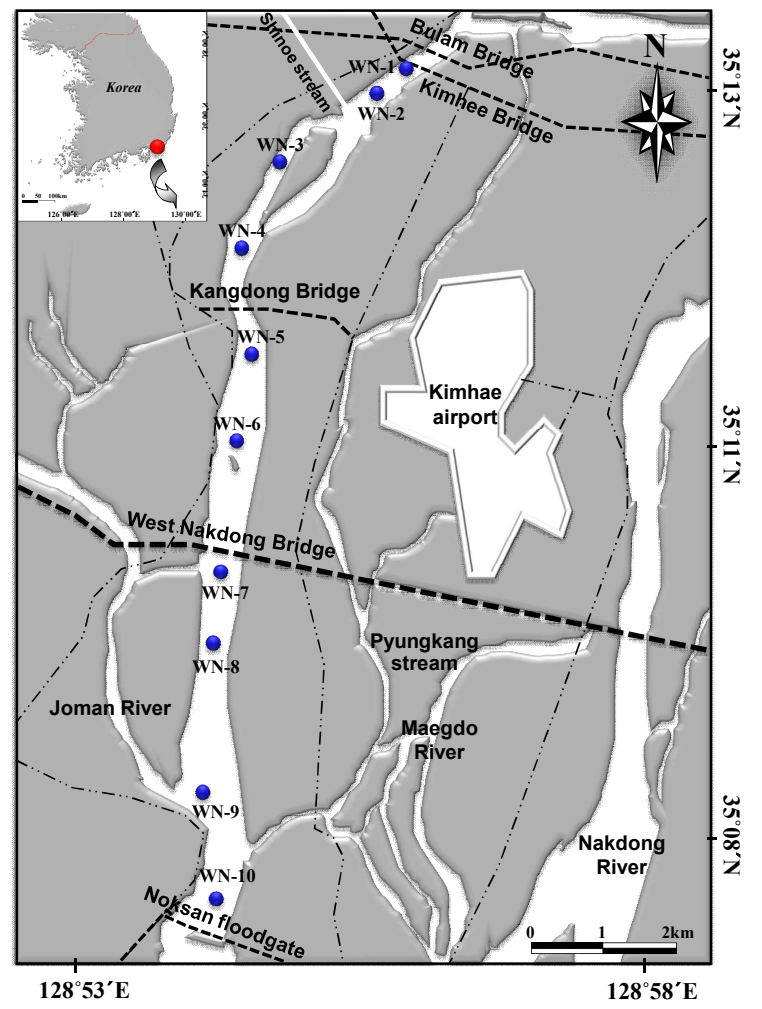

Fig. 1. Map showing sampling locations of surface sediments in the west Nakdong River.
$2 \mathrm{ml}$ 까지 농축하였으며, 농축된 추출액을 $n$ 헥산(ultra residue analysis, J.T. Baker, USA) $200 \mathrm{ml}$ 가 들어있는 분액여두에 넣은 다음 황산(Special grade, Wako, Japan)을 이용하여 유기 물을 분해시켰다. 황산 처리 후 농축액은 활성화된 구리를 이 용하여 황 화합물을 제거한 후, $130^{\circ} \mathrm{C}$ 에서 19 시간 동안 활성화 시킨 실리카겔(Wakogel S-1, PCB analysis grade, Wako, Japan) $3 \mathrm{~g}$ 이 충전된 컬럼크로마토그래피를 이용하여 정제하 였으며, 용리액으로서 $150 \mathrm{ml}$ 의 $n$ 헥산을 넣어 1 초 1 방울의 유속으로 추출액을 흘려보내 제 1 분획을 용출하였다. 다음 단 계로 $10 \%$ 염화메틸렌 $/ n$ 헥산을 흘려보내 제 2 분획을 취득하 였다. 각각의 용출액은 회전증발농축기를 이용하여 약 $2 \mathrm{ml}$ 까 지 농축하였으며, $\mathrm{PCBs}, \mathrm{HCB}, p, p^{\prime} \mathrm{DDE}$ 가 포함된 제 1 분획과 유기염소계농약류인 $\mathrm{HCHs}$, DDTs가 포함된 제2분획은 기체 크로마토그래프 내부표준물질(tetrachloro- $m$ xylene)을 첨가

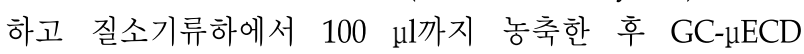
(Hewlett Packard 6890 Series GC, ${ }^{63} \mathrm{Ni}$ electron capture detector $\mu \mathrm{ECD}, \mathrm{USA})$ 를 이용하여 정성-정량 분석하였다.

분석에 이용된 컬럼은 DB-1 $(30 \mathrm{~m} \times 0.25 \mathrm{~mm}$ I.d., $0.25 \mu \mathrm{m})$ 이며, Carrier Gas는 질소를 이용 $1.0 \mathrm{ml} / \mathrm{min}$ 의 조건에서 시행 하였다. 유기염소계농약의 가스크로마토그래피의 온도 프로 그램은 인젝터 온도 $260^{\circ} \mathrm{C}$ 에서 splitless mode로 디텍터의 온 도는 $280^{\circ} \mathrm{C}$ 에서 검출하였다. 오븐의 운전조건은 $100^{\circ} \mathrm{C}(1 \mathrm{~min})$, $20^{\circ} \mathrm{C} / \mathrm{min}$ to $170^{\circ} \mathrm{C}, 5^{\circ} \mathrm{C} / \mathrm{min}$ to $280^{\circ} \mathrm{C}, 20^{\circ} \mathrm{C} / \mathrm{min}$ to $320^{\circ} \mathrm{C}(12$ $\mathrm{min})$ 으로 총 40 분의 운전조건으로 검출하였다. $\mathrm{PCBs}$ 는 인젝 터의 온도는 $240^{\circ} \mathrm{C}$ 에서 splitless mode로 디텍터의 온도는 $300^{\circ} \mathrm{C}$ 에서 검출하였다. 오븐의 운전조건은 $50^{\circ} \mathrm{C}(3 \mathrm{~min}), 15^{\circ} \mathrm{C} / \mathrm{min}$ to $160^{\circ} \mathrm{C}(3 \mathrm{~min}), 4^{\circ} \mathrm{C} / \mathrm{min}$ to $280^{\circ} \mathrm{C}(10 \mathrm{~min})$ 의 운전조건으로 검출하였다.

유기염소계화합물 표준물질은 순도, 농도 및 신뢰성이 검증 된 것을 구입하여 사용하였다. PCB 화합물은 Ultra Scientific 사에서 구매한 Aroclor-mixture (1242, 1248, 1254, 1260=1 : $1: 1: 1)$ 를 혼합한 혼합액을 표준용액으로 사용하여 총 86 개 이성질체를 분석하였다. 유기염소계농약인 $\mathrm{DDT}$ 화합물류 $\left(o, p=\mathrm{DDE}, \quad p, p^{\prime}-\mathrm{DDE}, \quad o p=\mathrm{DDD}, \quad p, p^{\prime}\right.$-DDD, $o p^{\prime}$-DDT, $p, p$-DDT), 헥사클로르사이클로헥산 화합물류 $(\mathrm{a}-\mathrm{HCH}, \quad \beta$ $-\mathrm{HCH}, \gamma-\mathrm{HCH}, \delta-\mathrm{HCH})$ 그리고 헥사클로르벤젠 $(\mathrm{HCB})$ 은 AccuStandard사에서 혼합액으로 구매하였다. 또한, 내부표준 물질로 사용된 4,4'-Dibromooctafluorobiphenyl과 2,4,5,6Tetrachloro-mxylene는 AccuStandard사에서 구매하여 $n$ 헥 산으로 조제, 희석하여 각각 $1.0 \mathrm{ng} / \mathrm{ul}, 2.0 \mathrm{ng} / \mathrm{ul}$ 농도로 만들 어 사용하였다.

내부표준물질로 첨가된 $\mathrm{DBOFB}, \mathrm{PCB} 103$ 및 $\mathrm{PCB}$ 198의 회수율은 각각 78 $105 \%, 82 \sim 94 \%$ 및 $68 \sim 108 \%$ 의 범위로 나타 났다. 검출한계는 Noise의 2 배의 면적을 검정공식에 적용하여 농도를 구한 후 시료량 $10 \mathrm{~g}$ 을 적용하여 구하였으며, 검출한계 는 PCBs $0.005 \sim 0.07 \mathrm{ng} / \mathrm{g}$, DDTs $0.003 \sim 0.05 \mathrm{ng} / \mathrm{g}$, HCHs 
$0.008 \sim 0.02 \mathrm{ng} / \mathrm{g}$ 그리고 HCB $0.005 \sim 0.03 \mathrm{ng} / \mathrm{g}$ 의 범위로 정량 치가 검출한계 이하일 경우에는 불검출로 처리하였다.

\section{통계분석}

상업용 PCBs 제품(Aroclor-1242, 1248, 1254, 1260)의 사용 으로 인한 발생원 해석을 위하여 사용한 통계분석법은 다변량 해석 수법의 하나인 주성분 분석(Principle component analysis, PCA)으로 주성분수의 결정은 고유치(Eigen value) 1 을 기 준으로 하여 분석하였다. 총 유기탄소(Total organic carbon, $\mathrm{TOC}$ )와 각 화합물 사이의 상관관계는 피어슨 상관분석 (Pearson correlation analysis)을 실시하였으며, 데이터의 통 계적 처리는 Statistica (Version 6.0, statsoft Inc., OK, USA) 프로그램을 이용하였다.

\section{결과 및 고찰}

\section{퇴적물 내 OCs의 수평적 농도분포}

서낙동강 표층퇴적물 내에 잔류하고 있는 유기염소계화합 물(Organochlorine compounds, OCs)과 총 유기탄소(Total organic carbon, TOC)의 농도를 Table 1에 나타내었다. 표층퇴 적물 내 유기염소계화합물의 평균농도와 표준편차는 $\Sigma \mathrm{PCBs}$ $1.81 \pm 0.87 \mathrm{ng} / \mathrm{g}$ (dry weight basis), $\Sigma$ DDTs $3.76 \pm 2.71 \mathrm{ng} / \mathrm{g}$, $\sum \mathrm{HCHs} 1.17 \pm 0.33 \mathrm{ng} / \mathrm{g}$ 그리고 최근 산업공정의 부산물 또는 불순물로 주로 발생되고 있는 $\mathrm{HCB}$ 는 $0.16 \pm 0.18 \mathrm{ng} / \mathrm{g}$ 로 DDT 화합물이 가장 높은 농도로 검출되었다.

서낙동강 유역내에는 덕암 산업단지, 삼계·지내 준공업지 역 및 주촌 - 내삼 농공단지 등의 배출원과 녹산수문으로 인한 수리학적 체류시간 증대와 함께 퇴적물의 증대로 유기염소계 화합물의 오염이 우려되어 왔으나, Table 2에 나타낸 바와 같 이 표층퇴적물 내의 $\Sigma \mathrm{PCBs}$ 농도는 국내의 형상강, 시화호, 낙동강하구의 표층퇴적물에서 검출된 농도에 비해 낮았다. 반 면, 유기염소계농약인 $\Sigma \mathrm{DDTs}$ 는 국내의 오염된 지역인 형상 강, 시화호에서 검출된 농도보다 높은 수준이었다. 이는 $\mathrm{PCB}$ 화합물의 경우, 주로 산업 및 도시 지역과 상관성이 있는 것으 로 알려져 있으나, 본 조사지역은 공업중심의 산업 지역은 일 부분이고 대부분 농업중심지역이라 $\Sigma \mathrm{PCBs}$ 의 농도는 낮은 반 면, 유기염소계농약인 $\Sigma \mathrm{DDTs}$ 의 농도가 높은 것으로 판단되 었다. 난연성 유기오염물질인 DDT 화합물은 자연환경에서 긴 생물 - 화학적 반감기를 가지고 있으며, 생물반감기는 최소 15 년이고 토양에서의 반감기는 18 20년으로 추정하고 있다[6,8].

본 조사지역 퇴적물 중 유기염소계화합물의 농도 수준을 국외의 여러 지역에서 검출된 농도와 비교해보면 $\Sigma \mathrm{PCBs}$ 농 도는 중국, 베트남 및 스페인의 강과 하구지역 퇴적물의 농도 보다 낮았으며, 인도의 강 하구에서 검출된 농도와 유사한 수 준이었다(Table 2). 유기염소계농약인 $\Sigma \mathrm{DDTs}, \Sigma \mathrm{HCHs}$ 는 우 리나라와 사용밀도가 비슷한 인도[17]와 유사하거나 다소 높
Table 1. Concentration (ng/g dry weight) of PCBs and organochlorine pesticides in surface sediment

\begin{tabular}{|c|c|c|c|c|}
\hline \multirow{2}{*}{ Paramter } & \multirow{2}{*}{ mean $\pm \mathrm{SD}^{a}$} & \multirow{2}{*}{ median } & \multicolumn{2}{|c|}{ Range } \\
\hline & & & $\min$ & $\max$ \\
\hline TOC (\%) & $1.21 \pm 0.56$ & 1.12 & 0.57 & 2.17 \\
\hline $\mathrm{di}-\mathrm{CBs}$ & $0.25 \pm 0.17$ & 0.21 & 0.033 & 0.63 \\
\hline tri-CBs & $0.55 \pm 0.35$ & 0.56 & 0.15 & 1.18 \\
\hline tetra-CBs & $0.48 \pm 0.28$ & 0.45 & 0.13 & 1.03 \\
\hline penta-CBs & $0.26 \pm 0.15$ & 0.24 & 0.035 & 0.47 \\
\hline hexa-CBs & $0.15 \pm 0.13$ & 0.13 & 0.023 & 0.48 \\
\hline hepta-CBs & $0.09 \pm 0.08$ & 0.083 & 0.008 & 0.31 \\
\hline octa-CBs & $0.02 \pm 0.03$ & 0.009 & N.D & 0.074 \\
\hline nona-CBs & $0.01 \pm 0.02$ & 0.002 & N.D & 0.044 \\
\hline$\sum \mathrm{PCBs}$ & $1.81 \pm 0.87$ & 1.84 & 0.57 & 3.68 \\
\hline$o \cdot p^{\prime}-\mathrm{DDE}$ & $0.34 \pm 0.32$ & 0.31 & N.D & 0.88 \\
\hline$p \cdot p^{\prime}-\mathrm{DDE}$ & $1.31 \pm 0.69$ & 1.19 & 0.06 & 2.26 \\
\hline$o \cdot p^{\prime}$-DDD & $0.41 \pm 0.49$ & 0.12 & N.D & 1.39 \\
\hline$p \cdot p^{\prime}$-DDD & $0.87 \pm 0.74$ & 0.75 & 0.11 & 2.12 \\
\hline$o p^{\prime}-\mathrm{DDT}$ & $0.27 \pm 0.29$ & 0.20 & N.D & 0.79 \\
\hline$p \cdot p^{\prime}$-DDT & $0.56 \pm 0.57$ & 0.33 & 0.014 & 1.65 \\
\hline$\sum$ DDTs & $3.76 \pm 2.71$ & 3.44 & 0.41 & 8.35 \\
\hline a-HCH & $0.21 \pm 0.13$ & 0.21 & 0.013 & 0.37 \\
\hline$\beta-\mathrm{HCH}$ & $0.61 \pm 0.16$ & 0.59 & 0.046 & 0.84 \\
\hline$\gamma-\mathrm{HCH}$ & $0.15 \pm 0.10$ & 0.12 & N.D & 0.31 \\
\hline$\delta-\mathrm{HCH}$ & $0.20 \pm 0.15$ & 0.25 & N.D & 0.42 \\
\hline$\sum \mathrm{HCHs}$ & $1.17 \pm 0.33$ & 1.19 & 0.63 & 1.65 \\
\hline $\mathrm{HCB}$ & $0.16 \pm 0.18$ & 0.12 & N.D & 0.56 \\
\hline
\end{tabular}

TOC: total organic carbon, SD: standard deviation.

N.D. is not detected: the measurement was below the detection limit.

${ }^{a}$ Percentiles calculated based on results for all $(n=30)$ samples.

은 수준이었다.

한편, Fig. 2에 나타낸 바와 같이 하류지역인 WN-10의 오염 도는 매우 높은 수준이었다. 이 지역에서의 높은 농도의 원인 으로 녹산수문에 의해 조류의 흐름이 차단되어 배출된 유기오 염물질이 퇴적물에 계속적으로 흡착되어 오염도가 높은 것으 로 판단되었다. 또한, 이 지역은 서낙동강 오염부하량의 약 $62 \%$ 를 차지하는 조만강과 산업폐수량의 유입이 많은 평강천 과 인접하고 있다. 하지만, 유기염소계화합물의 분포특성은 조사지역 주변특성에 따른 사용량의 차이, 휘발성, 옥타놀-물 분배계수(Octanol-water partition coefficient, $K_{\text {om }}$ ), 용해도, 분 해성 등의 물리 - 화학적인 특성과 같은 다양한 환경적 요인을 고려할 수 있어 보다 명확한 오염 발생원 규명을 위해서는 향후 서낙동강 지류에 대한 대상오염물질의 LCA (Life cycle analysis), 물질수지 등 과학적 방법을 통한 배출원 조사가 필 요할 것이다.

TOC는 유기염소계화합물의 분배를 좌우하는 중요한 요소 의 하나이다. $\mathrm{PCBs}$ 와 같이 높은 $\log K_{\mathrm{ow}}$ 와 낮은 물 용해도를 가진 유기염소계화합물은 물이나 대기 등 유체상 매체보다는 유기탄소를 함유한 고체상 퇴적물에 축적율이 비교적 높다 [23]. 유사하게 본 연구에서도 TOC 함량은 $\sum \mathrm{PCBs}(r=0.874$, $p<0.01), \sum \mathrm{DDTs}(r=0.762, p \times 0.05)$ 와 유의성 있는 양의 상관성 
Table 2. Comparison of PCBs and OCPs concentrations (ng/g dry weight basis) reported for surface sediments collected in various locations

\begin{tabular}{|c|c|c|c|c|c|}
\hline \multirow[b]{2}{*}{ Location } & $\sum \mathrm{PCBs}$ & $\sum$ DDTs & $\sum \mathrm{HCHs}$ & $\mathrm{HCB}$ & \multirow[b]{2}{*}{ References } \\
\hline & \multicolumn{4}{|c|}{ Range $(\min \sim \max )$} & \\
\hline West Nakdong River, Korea & $0.57 \sim 3.68$ & $0.41 \sim 8.35$ & $0.63 \sim 1.65$ & N.D 0.56 & This research \\
\hline Nakdong River, Korea & 1.10 141 & & & & [12] \\
\hline Hyeongsan River, Korea & $<1.0 \sim 170$ & $1.10 \sim 1.30$ & $0.01 \sim 1.31$ & $0.95 \sim 2.01$ & [15] \\
\hline Shihwa Lake, Korea & $9.05 \sim 126$ & $0.15 \sim 2.14$ & $0.55 \sim 10.7$ & $0.09 \sim 3.49$ & [14] \\
\hline Seomjin River, Korea & $0.32 \sim 1.79$ & $0.34 \sim 1.16$ & $0.05 \sim 0.36$ & & [16] \\
\hline Pearl River Estuary, China & $6.01 \sim 287$ & 1.37 599 & 11.9 353 & $1.08 \sim 55.5$ & [10] \\
\hline Hanoi Canals, Vietnam & $0.74 \sim 33.6$ & $7.40 \sim 80.5$ & $0.07 \sim 3.12$ & N.D 0.13 & [20] \\
\hline Hugli River Estuary, India & $0.18 \sim 2.33$ & $0.18 \sim 1.93$ & $0.11 \sim 0.40$ & $0.05 \sim 0.98$ & [11] \\
\hline Wu-Shi River, Taiwan & & N.D 11.4 & $0.99 \sim 14.5$ & & [7] \\
\hline Jarama River, Spain & $266 \sim 1,179$ & 107 969 & $0.03 \sim 38.2$ & & [9] \\
\hline
\end{tabular}

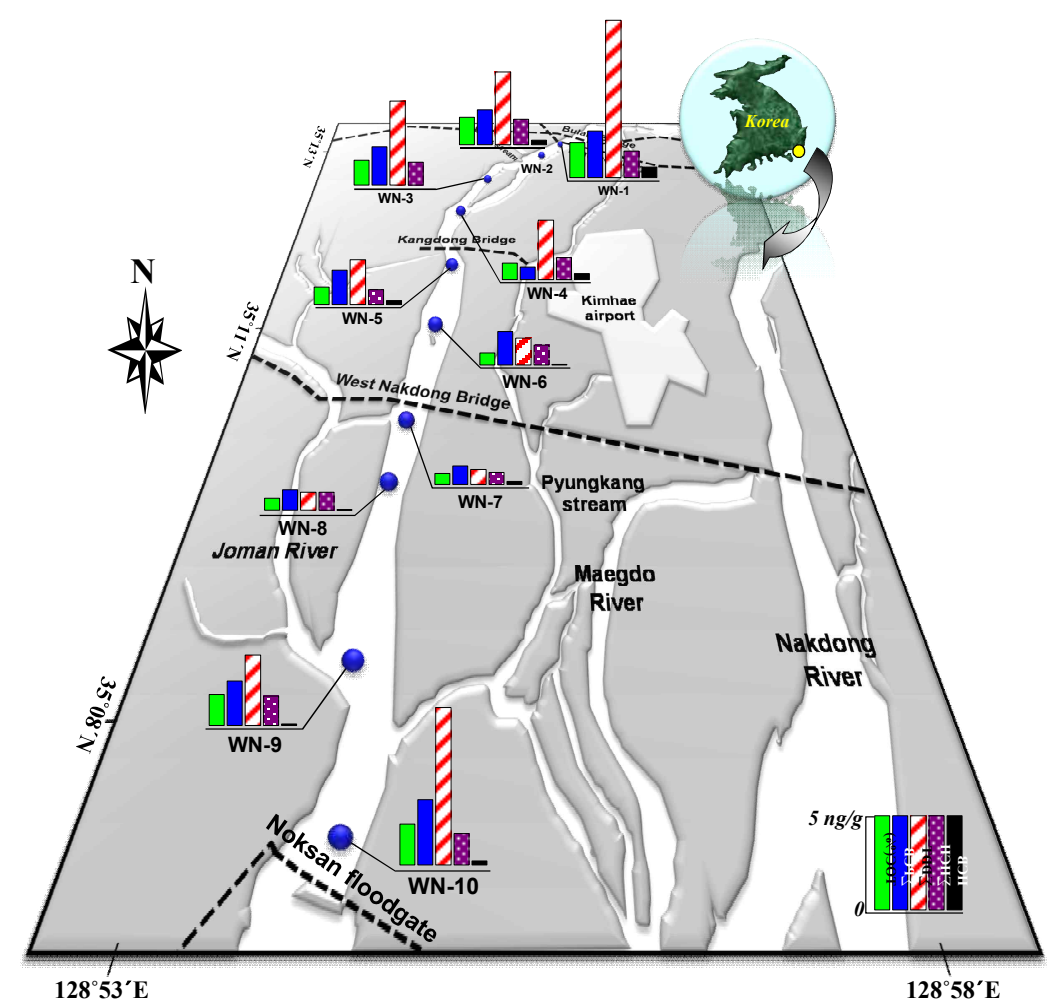

Fig. 2. Concentrations (ng/g, dry weight) of organochlorine compounds and total organic carbon (\%) in surface sediments.

이 관찰되어 서낙동강 수계에서 TOC 함량은 유기염소계화합 물의 수평적 분포에 작용하는 중요한 인자라고 판단되었다.

\section{오염원 및 이성질체 분포특성}

Fig. 3 에 나타낸 바와 같이, 표층퇴적물 내 $\Sigma \mathrm{PCBs}$ 의 동족체 분포패턴은 di-CBs, tri-CBs, tetra-CBs의 염소조성 비율이 각 각 13.5, 29.3 및 26.2\%로 저 염화물(low-chlorinated PCBs) PCBs가 약 $65 \%$ 이상을 차지하였으며, 고 염화물(high-chlorinated $\mathrm{PCBs}$ )인 octa-CBs, nona-CBs, deca-CBs는 $2 \%$ 이하의
낮은 구성비로 나타났다.

잠재적인 배출원을 파악하기 위하여 상업용 $\mathrm{PCBs}$ 제품인 Aroclor-1242, -1248, -1254, -1260의 구성성분과 $\Sigma \mathrm{PCBs}$ 농도 에 의해 각각 이성질체의 농도를 표준화시켜 주성분 분석 (Principal component analysis, PCA)에 적용하여 얻은 결과 를 Fig. 3에 나타내었다. 상업용 Aroclor 제품은 여러 $\mathrm{PCB}$ 동족 체들의 혼합물로 Aroclor-1242, -1248은 주로 di-CBs, tri-CBs, tetra-CBs등 주로 저 염화물이 주성분이며, Aroclor-1254는 tetra-PCBs, penta-CBs, hexa-PCBs, Aroclor-1260은 hexa-PCBs, 

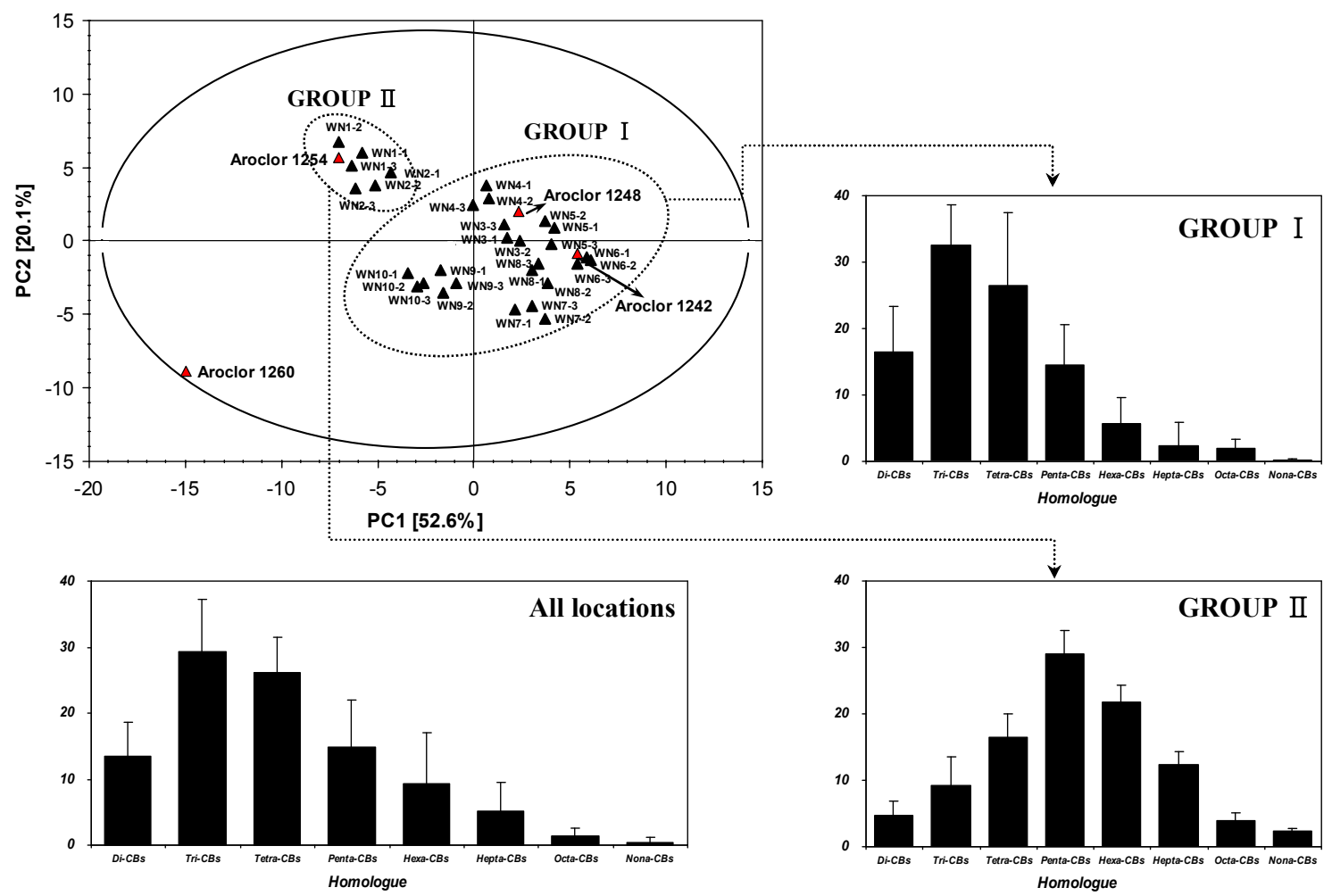

Fig. 3. PCA score plot for the composition of PCB congeners and Aroclor mixtures in surface sediments. Congener specific concentrations were normalized to total sediment concentrations at each site.



Fig. 4. Isomer compositions of DDTs and $\mathrm{HCH}$ in surface sediments.

hepta-PCBs 등이 주성분으로 구성되어 있다. Fig. 3에서와 같 이 주성분 분석 결과는 명확히 두 개 그룹으로 구성되어 있었 다. 그룹 I은 Aroclor-1242, -1248 과 di-CBs, tri-CBs, tetra-CBs 등 저 염화물이 높게 구성된 중 - 하류 지역이었으며, 그룹 II는 Aroclor-1254와 penta-CBs, hexa-PCBs 등으로 구성된 상류지 역이었다.
자연환경에 배출된 $\mathrm{PCBs}$ 의 분해속도나 생체전이속도 등은 이성질체의 구조적 특성에 따라 차이가 있으며, 물리·화학적 특성은 비페닐기에 치환된 염소수와 구성위치에 따라 좌우된 다[24]. 또한, 수계 중 PCBs는 비페닐기에 치환된 염소수가

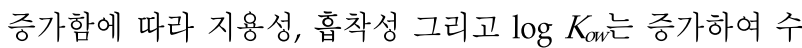
용성, 생물학적 분해성은 감소하므로[24] 산업생산 활동으로 
생성되는 육상기인 고분자량의 $\mathrm{PCBs}$ 는 하천수나 강우유출, 대기로부터의 침적 등의 다양한 이동경로를 통하여 배출원 근처의 퇴적물에 대부분 흡착 - 침적되나, 낮은 분배계수를 가 진 저분자량의 PCBs는 물에 잘 용해되어 배출원으로부터 멀 리 떨어진 중 - 하류 지역까지 이송되어 저분자량 $\mathrm{PCBs}$ 의 구 성 비율이 상대적으로 높은 분포양상을 띠고 있는 것으로 사 료된다.

$\mathrm{DDE}, \mathrm{DDD}, \mathrm{DDT}$ 의 농도는 각각 $1.65 \pm 0.87 \mathrm{ng} / \mathrm{g}, 1.28 \pm 1.17$ $\mathrm{ng} / \mathrm{g}, 0.83 \pm 0.84 \mathrm{ng} / \mathrm{g}$ 으로 검출되었으며, 살충 효과가 가장 강한 $p, p^{\prime}$-DDT는 $0.014 ~ 1.65 \mathrm{ng} / \mathrm{g}$ 의 범위로 평균 농도는 0.42 $\mathrm{ng} / \mathrm{g}$ 이었다(Table 1). $\Sigma \mathrm{DDTs}$ 농도에 대한 DDE, DDD, DDT 의 구성비는 각각 $52.2,30.8$ 및 $17.0 \%$ 로 DDT 보다 대사물질인 $\mathrm{DDE}, \mathrm{DDD}$ 의 구성비가 높게 나타났다(Fig. 4). 상업적으로 생 산된 $\mathrm{DDT}$ 제품(이하 technical $\mathrm{DDT}$ )의 구성비는 $p, p$-DDT $75 \%, o$-DDT $15 \%, p p^{\prime}$-DDE $5 \%$ 그리고 나머지 대사물질이 $5 \%$ 정도로 구성되어 있으나 퇴적물 내 $\mathrm{DDE}$ 와 $\mathrm{DDD}$ 의 백분율 증가는 사용규제 이후 축적된 DDT가 분해과정 중에 있음을 의미한다. DDT는 일반적으로 산화 또는 환원 조건, 미생물 작용 및 광분해 등에 의해 $\mathrm{DDE}$ 와 $\mathrm{DDD}$ 로 분해된다[13].

한편, $p, p^{\prime} \mathrm{DDT} / p p^{\prime}$-DDE의 비율이 0.33보다 높으면 $\mathrm{DDT}$ 의 유입이 최근에 이루어진 것으로 판단하는데[25], 본 연구결 과, $p, p^{\prime} \mathrm{DDT} / p, p^{\prime} \mathrm{DDE}$ 의 비율은 0.33 보다 작아, 최근 $\mathrm{DDT}$ 의 유입이 상대적으로 $p p^{\prime}$-DDE의 높은 농도보다 적은 수준임을 암시하고 있어 서낙동강 수계에서 최근 DDT 화합물의 유입은 없는 것으로 나타났다.

$\Sigma \mathrm{HCHs}$ 농도에 대한 a-, $\beta-, \gamma$ - 그리고 $\delta-\mathrm{HCH}$ 의 구성비는 각각 $17.9,51.7,13.2$ 및 $17.2 \%$ 로 미생물분해가 아주 느려 고안 정성인[30] $\beta-\mathrm{HCH}$ 의 농도가 가장 높았다(Fig. 4). 반면, 상업 용 $\mathrm{HCH}$ 혼합품 내 $\mathrm{a}-\mathrm{HCH}$ 의 높은 구성비(55 80\%)에도 불구 하고 퇴적물에서 낮은 농도로 검출된 것은 다른 동위체에 비 하여 $\mathrm{a}-\mathrm{HCH}$ 는 높은 증기압과 낮은 분해능 때문으로 설명될 수 있다. 또한, 퇴적물 내 $\mathrm{a}-\mathrm{HCH} / \gamma-\mathrm{HCH}$ 의 비율이 1.1로 상 업용 $\mathrm{HCH}$ 혼합품 내 $\mathrm{a}-\mathrm{HCH} / \gamma-\mathrm{HCH}$ 의 비율이 4 7에 비해 낮은 값을 나타내고 있는데, 이는 서낙동강 수계에 유입된 상 업용 $\mathrm{HCH}$ 가 사용 이후 오랜 시간이 경과되었으며, 최근에 유입된 상업용 $\mathrm{HCH}$ 가 상대적으로 적었음을 의미한다. 비록, 1970년대 이후 거의 모든 국가에서 사용이 금지되었으나 씨앗 세정 및 의료목적으로 캐나다와 미국을 포함한 몇몇 국가들에 서 사용되고 있다[27]. 현재 국내에서도 농업용이 아닌 의료목 적(이 제거약제)으로 $\mathrm{HCH}$ (상품명; lindane)이 사용되고 있다.

$\mathrm{HCB}$ 의 농도는 N.D $0.56 \mathrm{ng} / \mathrm{g}(0.16 \pm 0.18 \mathrm{ng} / \mathrm{g})$ 의 범위로 분석대상 물질 중 가장 낮은 농도로 검출되었다(Table 1). $\mathrm{HCB}$ 는 염소화합물 제조공정, 염소화반응, 소각과정 부산물 등으로 생성되어 대기를 통해 확산되는 특성을 지니고 있어 현재 거의 모든 환경시료에서 검출되고 있는 것으로 알려져 있는데[19] 본 연구결과에서도 국내에서 생산 및 사용된 적이
없는 $\mathrm{HCB}$ 가 검출되었다. $\mathrm{HCB}$ 의 대기 중 반감기는 2 6년, 토 양에서 반감기는 6년 이상으로 환경에 노출될 경우 잔류성이 매우 높다[1].

\section{잠재적 생태독성 영향}

수계에서 잔류성유기오염물질의 생물학적 영향 그리고 위 해성은 대부분 퇴적물 오염기준(Sediment Quality Guidline, $\mathrm{SQG}$ )을 이용하여 평가한다. SQG를 이용하여 서낙동강 퇴적 물 내의 저서생물에 대한 잠재적인 생태독성 영향을 평가한 결과를 Fig. 5 에 나타내었다. $\Sigma \mathrm{PCBs}$ 의 농도 수준은 0.57 3.68 $\mathrm{ng} / \mathrm{g}$ 의 범위로 저서생물에 $10 \%$ 악영향이 나타날 수 있는 농 도(Effect range low, ER-L) [22]인 $50 \mathrm{ng} / \mathrm{g}$ 과 최초영향수준 (Threshold effect level, TEL) [4]인 $21.5 \mathrm{ng} / \mathrm{g}$ 보다 낮아 독성 학적 관점에서 저서생물에 미치는 영향은 낮은 것으로 평가되 었다. $p p^{\prime}-\mathrm{DDD}, \gamma-\mathrm{HCH}$ 역시 잠정퇴적물권고기준(Interim Sediment Quality Guidelines, ISQG) [5]인 $3.54 \mathrm{ng} / \mathrm{g}, 0.94$ $\mathrm{ng} / \mathrm{g}$ 과 악영향 기대수준(Probable effects level, PEL) [5]인 $8.51 \mathrm{ng} / \mathrm{g}, 1.38 \mathrm{ng} / \mathrm{g}$ 을 초과하지 않았다.

그러나 $p p^{\prime}$-DDE는 전체 30 개 퇴적물 중 $30 \%$ 에서 그리고 $p, p^{\prime}$-DDT는 $17 \%$ 에서 ISQG인 $1.42 \mathrm{ng} / \mathrm{g}$ 와 $1.19 \mathrm{ng} / \mathrm{g}$ 을 초과 하였으며, $\Sigma \mathrm{DDTs}$ 역시 $0.41 ~ 8.35 \mathrm{ng} / \mathrm{g}$ 의 농도범위로 전체 $60 \%$ 의 퇴적물에서 TEL인 $3.89 \mathrm{ng} / \mathrm{g}$ 을 초과하였으나 저서생 물에 대한 악영향이 빈번하게 나타날 수 있는 악영향 기대수 준 $(\mathrm{PEL})$ 인 $51.7 \mathrm{ng} / \mathrm{g}$ 이하였다. 잠정퇴적물권고기준(ISQG)과 악영향 기대수준(PEL) 사이의 오염물질 농도는 저서생물에 대한 악영향이 가끔 발생하는 정도의 오염상태이다.

따라서 본 연구지역 퇴적물 내 축적되어 있는 $p, p^{\prime} \mathrm{DDE}$, $p, p^{\prime} \mathrm{DDT}, \Sigma \mathrm{DDTs}$ 의 오염농도는 독성학적 관점에서 저서생 물에 미치는 잠재적인 환경독성영향력이 가끔 발생하는 것으 로 평가되었으며, $\Sigma \mathrm{PCBs}, p, p-\mathrm{DDD}, \gamma-\mathrm{HCH}$ 의 오염농도는 저서생물에 미치는 악영향은 거의 없는 오염되지 않는 퇴적물 의 상태로 평가되었다.

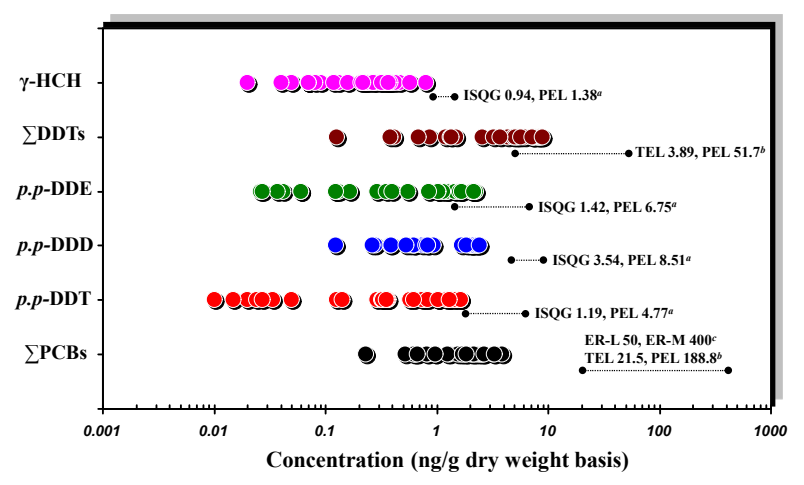

Fig. 5. The comparison of organochlorine concentrations in 30 sediment samples from the coast of korea with sediment qulity guidelines. ${ }^{a}$ ISQG, PEL[5], ${ }^{b}$ TEL, PEL[4], ${ }^{c}$ ERL, ERM [22]. 


\section{감사의 글}

본 연구는 2011학년도 경남대학교 학술연구장려금 지원에 의하여 수행되었으며, 이에 감사드립니다.

\section{References}

1. Benazon Environmental Inc. 1999. Hexachlorobezene Emissions/Releases Inventory for the Province of Ontario, 1988, 1998, and 2000 Draft Report, Submitted to Toxic Prevention Division. Environmental Protection Branch, Environment Canada.

2. Borga, K., G. W. Gabrielsen, and J. U. Skaare. 2001. Biomagnification of organochlorines along a Barents Sea food chain. Environ. Pollut. 113, 187-198.

3. Breivik, K., A. Sweetman, J. M. Pacyna, and K. C. Jones. 2002. Towards a global historical emission inventory for selected PCB congeners - a mass balance approach. 1. Global production and consumption. Sci. Total Environ. 290, 181-198.

4. Canadian Council of Ministers of the Environment, CCME. 2002. Canadian sediment quality guidelines for the protection of aquatic life. In: Canadian Environmental Quality Guidelines. Winnipeg Canada.

5. Canadian Council of Ministers of the Environment, CCME. 2003. Canadian sediment quality guidelines for the protection of aquatic life. In: Canadian Environmental Quality Guidelines. Winnipeg, Canada.

6. Carvalho, F. P., S. W. Fowler, J. P. Villeneuve, and M. Horvat. 1996. Pesticide residues in the marine environment and analytical quality assurance of the results. in: International Symposium on the Use of Nuclear and Related Techniques for Studying Environmental Behaviour of Crop Protection Chemicals. 1-July, Vienna. 35-57.

7. Doong, R. A., C. K. Peng, Y. C. Sun, and P. L. Liao. 2002. Composition and distribution of organochlorine pesticide residues in surface sediments from the Wu-Shi River estuary, Taiwan. Mar. Pollut. Bull. 45, 246-253.

8. European Environment Agency, EEA. 2002. Available from http://glossary.eea.eu.int/EEA Glossary/H/half-life of a pollutant.

9. Fernandez, M., S. Cuesta, O., Jimenez, M. A. Garcõa, L. M. Hernandez, M. L. Marina, and M. J. Gonzalez. 2000. Organochlorine and heavy metal residues in the water/sediment system of the Southeast Regional Park in Madrid, Spain. Chemosphere 41, 801-812.

10. Fung, C. N., G. J. Zheng, D. W. Connell, X. Zhang, H. L. Wong, J. P. Giesy, and Z. Fang. 2005. Risks posed by trace organic contaminants in coastal sediments in the Pearl River Delta, China. Mar. Pollut. Bull. 50, 1036-1049.

11. Guzzella, L., C. Roscioli, L. Vigano, M. Sahab, S. K. Sarkar, and A. Bhattacharya. 2005. Evaluation of the concentration of $\mathrm{HCH}, \mathrm{DDT}, \mathrm{HCB}, \mathrm{PCB}$ and $\mathrm{PAH}$ in the sediments along the lower stretch of Hugli estuary, West Bengal, northeast
India. Environ. Int. 31, 523-534..

12. Jeong, G. H., H. J. Kim, Y. J. Joo, Y. B. Kim, and H. Y. So. 2001. Distribution characteristics of PCBs in the sediments of the lower Nakdong River, Korea. Chemosphere 44, 1403-1411.

13. Klumpp, D. W., H. Huasheng, C. Humphrey, W. Xinhong, and S. Codi. 2002. Toxic contaminants and their biological effect in coastal waters of Xiamen, China. I. Organic pollutants in mussel and fish tissues. Mar. Pollut. Bull. 44, 752-760.

14. Koh, C. H., J. S. Khim, D. L. Villeneuve, K. Kannan, B. G. Johnson, and J. P. Giesy. 2005. Instrumental and bioanalytical measures of dioxin-like and estrogenic compounds and activities associated with sediment from the Korean coast. Ecotoxicol. Environ. Saf. 61, 366-379.

15. Koh, C. H., J. S. Khim, K. Kannan, D. L. Villeneuve, K. Senthilkumar, and J. P. Giesy. 2004. Polychlorinated dibenzo-pdioxins (PCDDs), dibenzofurans (PCDFs), biphenyls (PCBs), and polycyclic aromatic hydrocarbons (PAHs) and 2,3,7,8-TCDD equivalents (TEQs) in sediment from the Hyeongsan River, Korea. Environ. Pollut. 132, 489-501.

16. KORDI. 2003. A study on the management model for environmental pollution of special management area in Namhae: (I) Gwangyang Bay study. BSPE 836-001577-7.

17. Li, Y. F. 1999. Global technical hexachlorocyclohexane usage and its contamination consequences in the environment: from 1948 to 1997. Sci. Total Environ. 232, 121-158.

18. Li, Y. F. and R. W. Macdonald. 2005. Sources and pathways of selected organochlorine pesticides to the Arctic and the effect of pathway divergence on $\mathrm{HCH}$ trends in biota: a review. Sci. Total Environ. 342, 87-106.

19. Ministry of Maritime Affairs and Fisheries, MOMAF. 2001. The status of POPs contamination along the coast of Korea. Korea BSPM00070-00-1336-3.

20. Nhan, D. D., F. P. Carvalho, N. M. Am, N. Q. Tuan, N. T. H. Yen, J. P. Villeneuve, and C. Cattini. 2001. Chlorinated pesticides and PCBs in sediments and molluscs from freshwater canals in the Hanoi region. Environ. Pollut. 112, 311-320.

21. Nie, X., C. Lan, T. Wei, and Y. Yang. 2005. Distribution of polychlorinated biphenyls in the water, sediment and fish from the Pearl River estuary, China. Mar. Pollut. Bull. 50, 537-546.

22. NOAA. 1999. The potential for biological effects of sediment-sorbed contaminants tested in the noational status and trends program. NOAA Technical Memorandum NOS OMA 52, NOAA, Seattle, USA.

23. Pierard, C., H. Budzinski, and P. Garrigues. 1996. Grain-size distribution of polychlorobiphenyls in coastal sediments. Environ. Sci. Technol. 30, 2776-2783.

24. Rajendran, R. B., T. Imagawa, H. Tao, and R. Ramesh. 2005. Distribution of PCBs, HCHs and DDTs, and their ecotoxicological implications in Bay of Bengal, India. Environ. Int. 31, 503-512.

25. Strandberg, B. O., B. van Bavel, R. A. Rergqvist, D. Broman, R. Ishaq, C. Näf, H. Pettersen, and C. Rappe. 1998. 
Occurrence, sedimentation and spatial variations of organochlorine contaminants in settling particulate matter and sediments in the northern part of the Baltic Sea. Environ. Sci. Technol. 32, 1754-1759.

26. Strandberg, B., C. Bandh, B. van Bavel, P. A. Bergqvist, C. Broman, R. Ishaq, C. Näf, and C. Rappe. 2000. Organochlorine compounds in the Gulf of Bothnia: sediment and benthic species. Chemosphere 40, 1205-1211.

27. United Nations Environment Program, UNEP. 2002. Regionally based assessment of persistent toxic substances. South East Asia and South Pacific.

28. United Nations Environmental Program, UNEP. 2003. Stockholm Convention: Master List of Actions: on the reduction and/or elimination of the releases of persistent organic pollutants. Fifth eds. Geneva, Switzerland

29. We, S. U., K. H. Kim, B. H. Cho, Y. J. Cho, C. H. Yoon, and B. Y. Min. 2010. The Relationship among the Indicator PCBs in Breast Milk and Dietary Habits and Demographic Factors in Women Living in Urban Areas. J. Env. Hlth Sci. 36, 199-207.

30. Willett, K. L., E. M. Ulrich, and R. A. Hites. 1998. Differential toxicity and environmental fates of hexachlorocyclohexane isomers. Environ. Sci. Technol. 32, 2197-2207.

31. Zoeller, R. T. 2005. At the cutting edge. Environmental chemicals as thyroid hormone analogues: New studies indicate that thyroid hormone receptors are targets of industrial chemicals. Mol. Cell Endocrinol. 242, 10-15.

\section{초록 : 서낙동강 수계 퇴적물 내 $\mathrm{PCBs}, \mathrm{DDTs}, \mathrm{HCHs}$ 및 $\mathrm{HCB}$ 의 수평적 분포와 잠재적 생태독성 영 향 평가 \\ 위성욱 · 윤조희 · 민병윤* \\ (경남대학교 도시환경공학과)}

본 연구는 서낙동강 표층퇴적물 내에 잔류하고 있는 유기염소계화합물의 수평적 분포와 잠재적 생태독성 영향 력을 평가하였다. 표층퇴적물 내 $\mathrm{PCBs}, \mathrm{DDTs}, \mathrm{HCHs}$ 및 $\mathrm{HCB}$ 의 잔류농도는 각각 $0.57 \sim 3.68,0.41 ~ 8.35,0.63 \sim 1.65$ 및 $\mathrm{n.d} ~ 0.56 \mathrm{ng} / \mathrm{g}$ 의 범위로 주요 유기염소계화합물은 DDT 화합물이었다. PCBs, DDTs 농도와 총 유기탄소 함량 은 유의한 상관관계(PCB: $r=0.874, p<0.001$, and DDTs: $r=0.762, p<0.05$ )를 보여 서낙동강 수계에서 퇴적물 내 유 기물 함량은 유기염소계화합물의 수평적 분포에 작용하는 주요 인자로 나타났다. 퇴적물 오염기준을 이용하여 서낙동강 표층퇴적물의 저서생물에 대한 잠재적인 생태독성 영향을 평가한 결과 $\Sigma \mathrm{PCBs}, p, p$-DDD 그리고 $\gamma$ $-\mathrm{HCH}$ 의 농도는 ER-L (저서생물에 $10 \%$ 악영향이 나타날 수 있는 농도)과 PEL (악영향 기대수준)보다 낮아 독성 학적 관점에서 저서생물에 미치는 악영향은 낮은 것으로 평가되었다. 그러나 $p, p$ - $\mathrm{DDE}, p, p$-DDT 및 $\Sigma \mathrm{DDTs}$ 는 각각 30,17 및 $19 \%$ 의 퇴적물에서 잠정퇴적물권고기준(ISQG)과 최초영향수준(TEL)을 초과하였다. 